\title{
Preparation and Application of LDPE/ZnO Nanocomposites for Extending Shelf Life of Fresh Strawberries
}

\author{
Aryou Emamifar ${ }^{1 *}$ and Mehri Mohammadizadeh ${ }^{2}$ \\ ${ }^{1}$ Department of Food Science and Technology, University of Kurdistan, \\ 66177-15177 Pasdaran Street, Sanandaj, Kurdistan, Iran \\ ${ }^{2}$ Department of Food Science and Technology, Science and Research Branch, \\ Islamic Azad University of Kurdistan, 6616935391, Feiz Abad, Sanandaj, Kurdistan, Iran
}

Received: July 15, 2014

Accepted: May 22, 2015

\begin{abstract}
Summary
Strawberries have a very short post-harvest life mostly due to their relatively high water content, intense metabolic activity and susceptibility to microbial rot. Antimicrobial low-density polyethylene nanocomposite films containing $\mathrm{ZnO}$ nanoparticles at different mass fractions were prepared by melt mixing and followed by compression moulding using a hot press machine. Fresh strawberries were packed in nanocomposite films and stored at $4{ }^{\circ} \mathrm{C}$. Their microbial stability, ascorbic acid content and titratable acidity were evaluated after $0,4,8,12$ and 16 days of storage. Microbial growth rate was significantly reduced up to 16 days as a result of the use of nanocomposite packaging material containing $\mathrm{ZnO}$ nanoparticles. By increasing the $\mathrm{ZnO}$ nanoparticle mass fraction to $5 \%$, the antimicrobial activity of the film increased. All packages containing the $\mathrm{ZnO}$ nanoparticles kept the microbial load of fresh strawberries below the level that affects shelf life (5 log $\mathrm{CFU} / \mathrm{g}$ ) up to 16 days. The lowest degradation of ascorbic acid content (6.55 $\mathrm{mg}$ per $100 \mathrm{~g})$, and loss of acidity (0.68 \%) were observed in packages containing $3 \%$ of $\mathrm{ZnO}$ nanoparticles with $10 \%$ polyethylene-grafted maleic anhydride.
\end{abstract}

Key words: strawberry, $\mathrm{ZnO}$ nanoparticles, nanocomposite, antimicrobial packaging

\section{Introduction}

Strawberries are highly perishable mainly due to fungal decay. Their post-harvest shelf-life at low temperatures $\left(0-4{ }^{\circ} \mathrm{C}\right)$ is approx. 5 days $(1,2)$. Among fresh fruits and vegetables, strawberries are especially interesting because they are fragile and sensitive to mould, which causes significant loss on the market (3). The loss of strawberries during storage can reach $40 \%$ (4). Therefore, many strategies have been developed to reduce the strawberry loss (5). Due to the shortcomings of the existing technologies, as well as to consumer demands, the development of alternative, preferably non-thermal approaches to processing of fresh produce is needed (6-8). Although some nonthermal approaches, such as pulsed electric field, high hydrostatic pressure, infrared, ultraviolet and ultrasonic treatments, for decontamination of fresh whole fruits are currently used (9-14), they have relatively limited commercial applications because they are energy-intensive, difficult to adapt, require costly equipment and lack suitable industrial scale processing units $(8,15)$. Nanotechnology has recently been introduced in the food packaging industry to provide solutions to challenges such as short shelf life and to improve antimicrobial packaging $(8,16)$. Antimicrobially active packaging is a new generation of food packaging based on nanocomposites made by incorporating metal nanoparticles into polymer films (17). It ensures microbial safety of food, and can extend the shelf life of products (18). There is a better interaction between polymer matrix and filler in 
the nanocomposite polymers than in conventional composites. The uniform distribution of nanoparticles in the polymer matrix increases the contact surface of the matrix with the particles, which leads to mechanical and thermal improvement (19). Low-density polyethylene (LDPE) is widely used because of its properties such as acceptable flexibility, transparency, low cost, easy processability and thermal stability $(20,21)$. ZnO nanoparticles have several industrial uses (22). $\mathrm{ZnO}$ has found many applications in daily life, e.g. in drug delivery, cosmetics and medical devices (23) due to its strong antimicrobial effect against a broad spectrum of microorganisms (24). Moreover, it is currently listed as generally recognized as safe (GRAS) material by Food and Drug Administration (FDA) (25). The antimicrobial activity of $\mathrm{ZnO}$ nanoparticles may be related to several mechanisms including the induction of oxidative stress in microorganisms and release of $\mathrm{Zn}$ ions from the surface of nanoparticles that bind to the cell membrane, which may cause its degradation. However, the mechanism of toxicity is still only partially understood (26). Since $\mathrm{ZnO}$ nanoparticles are thermally stable and thermal processing is used to produce the LDPE film, melt mixing can improve the properties of the nanocomposite $(27,28)$. The purpose of this study is to investigate the application of nanocomposite packaging consisting of LDPE film and $\mathrm{ZnO}$ nanoparticles as a new approach to preservation and prolonging shelf life of fresh strawberries.

\section{Materials and Methods}

\section{Preparation of antimicrobial nanocomposite films}

Film-grade LDPE resin pellets (LF0200, melt flow index (MFI) $2 \mathrm{~g}$ per $10 \mathrm{~min}$, density $0.92 \mathrm{~g} / \mathrm{mL}$, softening point $94^{\circ} \mathrm{C}$ ), polyethylene-grafted maleic anhydride (PE-g-MA) containing $1 \%$ malic anhydride and antimicrobial agents including $\mathrm{ZnO}$ nanoparticle powder with an average particle diameter of about 10-30 nm were obtained from Pishgaman Nano Material, Tehran, Iran. The film-grade LDPE resin pellets $(0.9 \mathrm{~kg})$ were mixed directly with the $\mathrm{ZnO}$ nanoparticles $(0.1 \mathrm{~kg})$ and the mixture was fed into a twin-screw extruder machine with a screw diameter of $55 \mathrm{~mm}$ and a screw length/diameter ratio of 30 $\mathrm{mm}$ (Brabender GmbH \& Co. KG, Duisburg, Germany) to be cut into masterbatch granules. Prior to compression moulding, the masterbatch and film-grade LDPE blends were again dried overnight in the vacuum oven at $50{ }^{\circ} \mathrm{C}$. It was particularly important to complete this step before compression moulding because the remaining water in the blend may cause the formation of air bubbles in the samples. Appropriate amounts of masterbatch resins were then added to pure LDPE resin pellets and put into a single-screw blowing machine with a screw diameter of 45 $\mathrm{mm}$ and a length/diameter ratio of $28 \mathrm{~mm}$ (Venus Plastic Machinery, Chia-Yi Region, Ming Shung Shian, Taiwan) to make the final nanocomposite. Hot press (Polystat 200T, Brabender GmbH \& Co. KG) with an attached water-cooling system was used to make the final nanocomposite films ( $0.09 \mathrm{~mm}$ thick) with the desired nanomaterial mass fractions $(1,3$ and $5 \%$ of $\mathrm{ZnO}$ nanoparticles, $3 \% \mathrm{ZnO}$ nanoparticles with $10 \%$ PE-g-MA as a compatibilizer, and pure LDPE film as a control). The compression moulder was heated to $180{ }^{\circ} \mathrm{C}$ for $30 \mathrm{~min}$ prior to use. The material was first pressed at low pressure for $4 \mathrm{~min}$, followed by a high-pressure cycle at $1034 \mathrm{kPa}$ for $6 \mathrm{~min}$. The samples were then cooled under pressure (483 Pa) for 5-7 min. Film thickness was measured using a micrometer (Mitutoyo Corp, Kawasaki, Kanagawa, Japan) and reported as the average of five readings taken at five different points on the film sample.

\section{Transmission electron microscopy analysis}

Cross-section samples for transmission electron microscopy (TEM) were prepared by ultramicrotomy and the slices were placed on a standard amorphous formvar/ carbon film on a copper grid (300 mesh). Dispersion quality of nanomaterials into the polymer matrix film was monitored using transmission electron microscope (Zeiss EM 10 C, 80 kV; Merck, Darmstadt, Germany).

\section{Determination of mechanical properties}

Young's modulus and elongation at break of the LDPE (control) and LDPE nanocomposite films were tested according to ASTM (American Society for Testing and Materials) D882-12 method (29) using universal material-testing machine (Zwick Testing Machines Ltd, Leominster, Herefordshire, UK) at $25{ }^{\circ} \mathrm{C}$ and $40 \%$ relative humidity (RH). Five identical specimens, in the shape of a strip of approx. $50 \mathrm{~mm}$ in length, $10 \mathrm{~mm}$ in width and 0.05 $\mathrm{mm}$ in thickness, were tested for each sample. The speed of the moving clamp was $500 \mathrm{~mm} / \mathrm{min}$.

\section{Preparation of packages for fresh strawberries}

Strawberries (Fragaria ananassa cv. Paros) were harvested at the last stage of commercial ripeness. Early in the morning they were transported to the post-harvest laboratory and were sorted to obtain homogeneous batches based on colour, size, absence of injuries and ripeness. Packages were prepared with a manual heat sealer using antimicrobial nanocomposite and pure LDPE films, 15 $\mathrm{cm} \times 10 \mathrm{~cm}$ in size. They were immediately wrapped in aluminium foil and sanitised at $95^{\circ} \mathrm{C}$ for $2 \mathrm{~min}$. After cooling under a sterile laboratory hood, fresh strawberries were selected randomly and immediately packed in 15 $\mathrm{cm} \times 10 \mathrm{~cm}$ nanocomposite and pure LDPE films.

\section{Storage of packed strawberries}

Strawberries were packed in 75 packages, each containing ten pieces of fruit, of the capacity of $20 \mathrm{~g}$ and stored in dark and cool conditions at $(4 \pm 1){ }^{\circ} \mathrm{C}$ and $(75 \pm 5)$ $\%$ RH. Microbiological and physicochemical characteristics (ascorbic acid degradation and titrable acidity) of the samples were evaluated in triplicate immediately after packaging and after 4, 8, 12 and 16 days of storage.

\section{Microbiological evaluations}

Tenfold dilutions of the suspension of strawberries in sterile peptone water $(0.1 \%)$ were prepared. Total aerobic plate counts were determined by pouring $0.1 \mathrm{~mL}$ of diluted suspensions on the plate count agar (PCA; Scharlau Chemie, S.A., Barcelona, Spain) incubated at $30{ }^{\circ} \mathrm{C}$ for 3 days. Total yeast and mould counts were determined by 
spreading the suspensions on the plates with potato dextrose agar (PDA; Scharlau Chemie, S.A.) containing $10 \%$ tartaric acid, which were incubated at $25{ }^{\circ} \mathrm{C}$ for 5 days. Each measurement was performed in duplicate and the results were expressed in colony-forming units (CFU) per gram.

\section{Degradation of ascorbic acid in strawberry samples}

Ascorbic acid is easily oxidised and its degradation is mainly determined by the method that relies on the reduction of 2,6-dichlorophenolindophenol reagent. In this work ascorbic acid degradation was determined using the titrimetric method (30).

\section{Determination of titrable acidity}

Titrable acidity of the samples was measured with a $\mathrm{pH}$ meter (laboratory $\mathrm{pH} / \mathrm{mV} / \mathrm{ORP}$ meter, model BT-600, $220 \mathrm{~V}$; Boeco, Hamburg, Germany) at $\mathrm{pH}=8.1$ with $0.1 \mathrm{M}$ $\mathrm{NaOH}$. It was expressed in percentage calculated from $\mathrm{g}$ of citric acid per $100 \mathrm{~g}$ of strawberry sample (31).

\section{Statistical analysis}

Analysis of variance was carried out using the SAS statistical software v. 6.12 (32), based on completely randomised designs. Differences among the data were significant at $\mathrm{p}<0.05$.

\section{Results and Discussion}

\section{Transmission electron microscopy images of films}

Fig. 1 shows the TEM images of LDPE films containing different mass fractions of $\mathrm{ZnO}$ nanoparticles. As
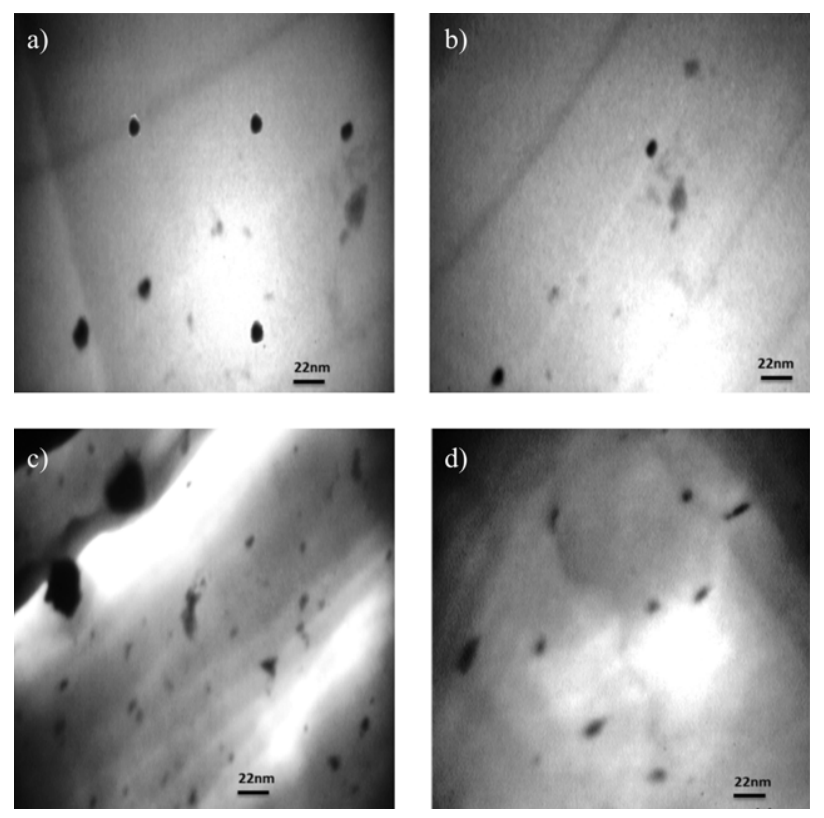

Fig. 1. Transmission electron microscopy images of antimicrobial nanocomposites: a) LDPE films with $1 \% \mathrm{ZnO}$ nanoparticles, b) LDPE films with $3 \% \mathrm{ZnO}$ nanoparticles, c) LDPE films with $3 \% \mathrm{ZnO}$ nanoparticles and $10 \%$ PE-g-MA, and d) LDPE films with $5 \% \mathrm{ZnO}$ nanoparticles shown, $\mathrm{ZnO}$ nanoparticles are well distributed in the polymer matrix. However, a slight agglomeration is observed when the mass fraction of $\mathrm{ZnO}$ nanoparticles is increased to $1 \%$ (Fig. 1a) possibly because of the strong attraction of nanoparticles. The TEM images of nanocomposite LDPE film with $3 \% \mathrm{ZnO}$ nanoparticles and PE-g-MA show that the nanoparticles are well dispersed in the polymer matrix, with aggregates ranging from 10 to 20 $\mathrm{nm}$ with an average size of $16 \mathrm{~nm}$ (Figs. 1c and d). The agglomeration can be reduced with the addition of compatibilizer because PE-g-MA not only acts as a compatibilizer inside the composite but also as a separator of the agglomerations inside the composites (33). As the mass fraction of $\mathrm{ZnO}$ nanoparticles increases to $5 \%$, the quantity of the agglomerates increases and their size becomes more uneven (Fig. 1d). It is well-known that this depends on several morphological and molecular parameters of nanofillers and polymer matrix. Moreover, the dispersion of nanoparticles is another important factor that affects the performance of nanocomposites. As shown in Table 1, the LDPE film with $3 \% \mathrm{ZnO}$ nanoparticles and the LDPE with $3 \% \mathrm{ZnO}$ nanoparticles and $10 \%$ PE-g-MA show better mechanical performances in comparison with the LDPE with $1 \% \mathrm{ZnO}$ nanoparticles and the LDPE with 5 $\% \mathrm{ZnO}$ nanoparticles. This correlates well with TEM micrograph records that are shown in Fig. 1.

Table 1. Effect of $\mathrm{ZnO}$ nanoparticles on the mechanical properties of LDPE films

\begin{tabular}{|c|c|c|c|}
\hline \multirow[t]{2}{*}{ Film type } & $\begin{array}{l}\text { Young's } \\
\text { modulus }\end{array}$ & $\begin{array}{c}\text { Tensile } \\
\text { strength }\end{array}$ & $\begin{array}{c}\text { Elongation } \\
\text { at break }\end{array}$ \\
\hline & $\mathrm{MPa}$ & $\mathrm{MPa}$ & $\%$ \\
\hline Pure LDPE & $(237.5 \pm 3.5)^{\mathrm{e}}$ & $(10.07 \pm 0.04)^{\mathrm{dc}}$ & $(150.5 \pm 3.6)^{\mathrm{a}}$ \\
\hline LDPE with $1 \% \mathrm{ZnO}$ & $(367.5 \pm 2.1)^{c}$ & $(9.1 \pm 0.1)^{\mathrm{d}}$ & $(28.1 \pm 2.5)^{\mathrm{d}}$ \\
\hline LDPE with $3 \% \mathrm{ZnO}$ & $(384 \pm 6)^{b}$ & $(13.4 \pm 0.2)^{b}$ & $(51.4 \pm 1.2)^{c}$ \\
\hline LDPE with $5 \% \mathrm{ZnO}$ & $(326 \pm 6)^{d}$ & $(10.9 \pm 0.8)^{c}$ & $(45.3 \pm 4.8)^{\mathrm{dc}}$ \\
\hline $\begin{array}{l}\text { LDPE with } 3 \% \mathrm{ZnO} \\
\text { and } 10 \% \text { PE-g-MA }\end{array}$ & $(671.5 \pm 2.1)^{\mathrm{a}}$ & $(23.7 \pm 0.6)^{\mathrm{a}}$ & $(78.8 \pm 5.7)^{\mathrm{b}}$ \\
\hline
\end{tabular}

Values are expressed as mean \pm standard deviation. Values with different letters in superscript in the same column are statistically different at $\mathrm{p}<0.05$

\section{Mechanical properties of nanocomposite films}

Stress-strain curves from tensile tests of LDPE/ZnO nanocomposites are shown in Fig. 2. Tensile strength, elongation at break and Young's modulus were determined from stress-strain curves as shown in Table 1. A significant increase can be observed in Young's modulus of all the LDPE/ZnO nanocomposites, while the elongation at break decreased significantly in all the tested films. There were no significant differences in the tensile strength between pure LDPE films and the LDPE with 1 and $5 \% \mathrm{ZnO}$ nanoparticles, while the LDPE with $3 \%$ $\mathrm{ZnO}$ nanoparticles had a greater tensile strength, Young's modulus and elongation at break, suggesting that the fine nanoparticles reinforced the films and were orientated along the direction of stress, which contributed to the increase of tensile strength. The highest values of Young's modulus $(671.5 \mathrm{MPa})$, tensile strength $(23.7 \mathrm{MPa})$ and 


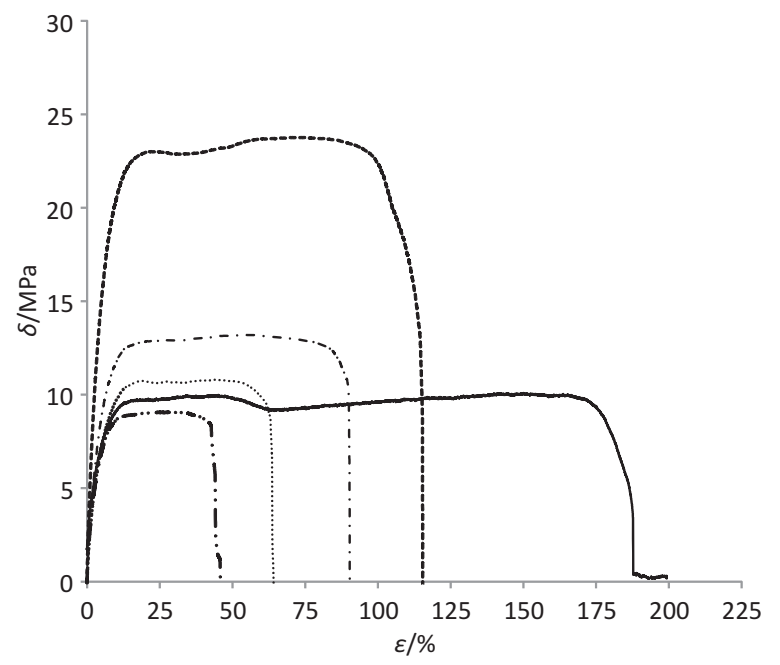

Fig. 2. Stress-strain diagrams of pure LDPE films (-), LDPE films with $1 \% \mathrm{ZnO}$ nanoparticles (-・-), LDPE films with $3 \%$ $\mathrm{ZnO}$ nanoparticles (---), LDPE films with $5 \% \mathrm{ZnO}$ nanoparticles ( $\cdots)$ and LDPE films with $3 \% \mathrm{ZnO}$ nanoparticles and $10 \%$ PE-g-MA (---)

elongation at break $(78.8 \%)$ were obtained in the LDPE films with $3 \% \mathrm{ZnO}$ nanoparticles and $10 \%$ PE-g-MA compared with other nanocomposite films (Table 1). The addition of PE-g-MA into nanocomposite films containing $3 \% \mathrm{ZnO}$ nanopartcles as a compatibilizer improved stress at break due to the significant interfacial adhesion and interaction between the LDPE matrix and $\mathrm{ZnO}$ nanoparticles. This improvement correlated well with the good dispersion of $\mathrm{ZnO}$ nanoparticles into the LDPE matrix, which enhanced the interaction between the molecules (Fig. 1c). Without the addition of compatibilizer, interfacial adhesion between the LDPE films and $\mathrm{ZnO}$ nanoparticles was weak, which prevented the formation of nanocomposite films $(33,34)$. Based on the results shown in Fig. 1d, the high amount of nanoparticle loadings (5\%) did not contribute to the homogeneous interactive bonding with the LDPE. It reduced the reinforcing effect and mechanical properties of the nanocomposite due to poor dispersion and agglomeration of $\mathrm{ZnO}$ nanoparticles. The weak interaction between the particles and the matrix caused weaker mechanical properties of LDPE films with $5 \% \mathrm{ZnO}$ nanoparticles compared with those with $3 \% \mathrm{ZnO}$ nanoparticles due to the debonding of particles from the matrix prior to its plastic deformation (Table 1). It seems that LDPE films with $1 \% \mathrm{ZnO}$ nanoparticles have weaker elongation at break compared with other nanocomposites (Fig. 2). Poor dispersion due to agglomeration of the nanoparticles has been known to be one of the main causes of weak elongation at break (Fig. 1a).

\section{Microbiological counts in packaged strawberries}

Immediately after packaging of fresh strawberries the mean initial population of yeast and moulds was determined to be $3.17 \log \mathrm{CFU} / \mathrm{g}$ and of total aerobic bacteria $2 \log \mathrm{CFU} / \mathrm{g}$. The variations in the population of yeast and moulds, and total aerobic bacteria are shown in Figs. 3 and 4, respectively. Microbial population in strawber-

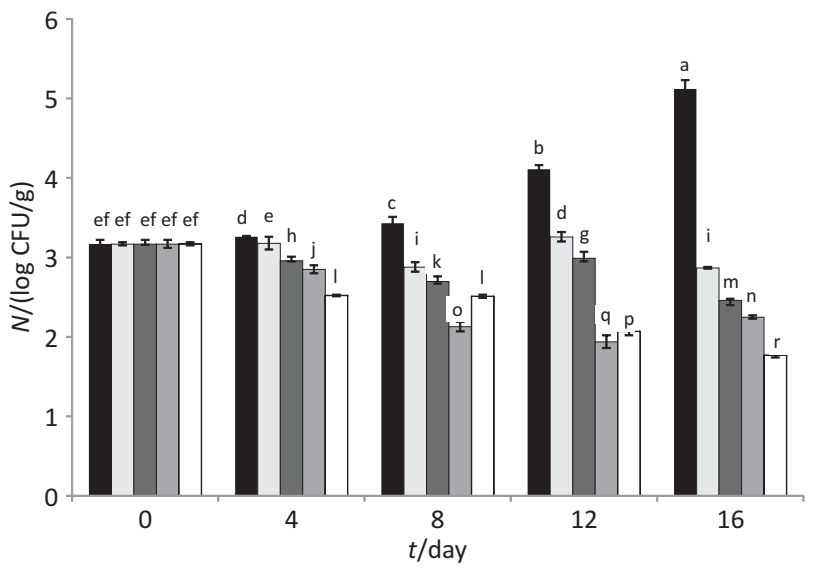

Fig. 3. Effect of packaging ( $\square$ pure LDPE films, $\square$ LDPE films with $1 \% \mathrm{ZnO}$ nanoparticles, $\square$ LDPE films with $3 \% \mathrm{ZnO}$ nanoparticles, $\square$ LDPE films with $5 \% \mathrm{ZnO}$ nanoparticles and $\square$ LDPE films with $3 \% \mathrm{ZnO}$ nanoparticles and $10 \%$ PE-g-MA) on the mould and yeast population of fresh strawberries during 16 days storage at $4{ }^{\circ} \mathrm{C}$. Different letters indicate significant differences at $p<0.05$ between the nanocomposite packagings containing different mass fractions of $\mathrm{ZnO}$ nanoparticles and pure LDPE packaging

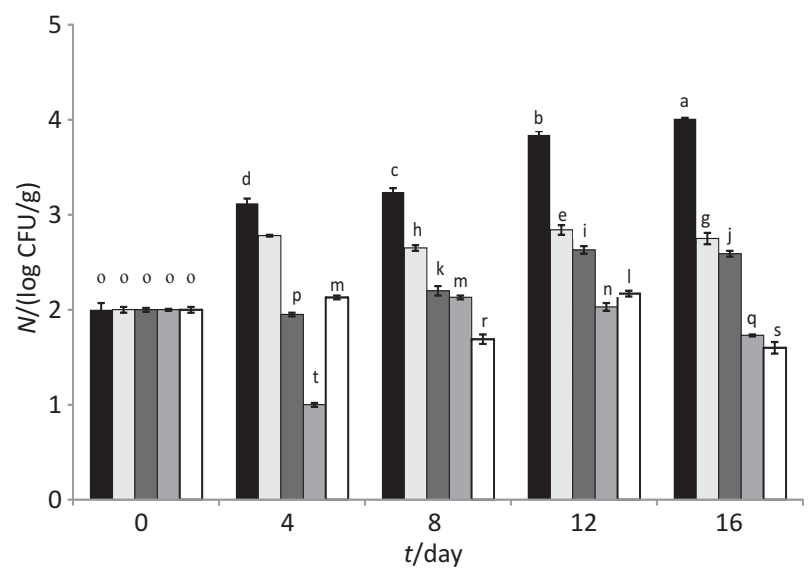

Fig. 4. Effect of packaging ( $\square$ pure LDPE films, $\square$ LDPE films with $1 \% \mathrm{ZnO}$ nanoparticles, $\square$ LDPE films with $3 \% \mathrm{ZnO}$ nanoparticles, $\square$ LDPE films with $5 \% \mathrm{ZnO}$ nanoparticles and $\square$ LDPE films with $3 \% \mathrm{ZnO}$ nanoparticles and $10 \%$ PE-g-MA) on the total aerobic bacterial count of fresh strawberries during 16 days storage at $4{ }^{\circ} \mathrm{C}$. Different letters indicate significant differences at $\mathrm{p}<0.05$ between nanocomposite packagings containing different mass fractions of $\mathrm{ZnO}$ nanoparticles and pure LDPE packaging

ries increased when storage time was increased to 16 days in all packages with pure LDPE films (5.12 log CFU/g of yeast and moulds and $4.01 \log \mathrm{CFU} / \mathrm{g}$ of total aerobic bacteria). However, the addition of $\mathrm{ZnO}$ nanoparticles into packaging resulted in a significantly lower microbial load during storage than in packages with pure LDPE films. By increasing the mass fraction of $\mathrm{ZnO}$ nanoparticles to 5 $\%$, the antimicrobial activity of the films increased (Figs. 3 and 4). However, it seems that the LDPE films with $3 \%$ $\mathrm{ZnO}$ nanoparticles and PE-g-MA had a significantly $(p<0.05)$ higher antimicrobial activity compared with other nanocomposites over 16 days of storage at $4{ }^{\circ} \mathrm{C}$, indicating a considerable effect of PE-g-MA on the increase of antimicrobial activity of nanocomposite LDPE films. 
Moreover, in the LDPE films with $3 \% \mathrm{ZnO}$ nanoparticles and PE-g-MA, significant decreases in the yeast and mould population were observed during 16 days of storage compared to the packages containing the same mass fraction of $\mathrm{ZnO}$ nanoparticles. The addition of PE-g-MA into the nanocomposite films as a compatibilizer improved the dispersion of nanoparticles into polymer matrix and caused good interaction between the LDPE matrix and $\mathrm{ZnO}$ nanoparticles (33). The mean population of yeast and moulds after 16 days of storage remained below the mean initial population ( $3.17 \log$ CFU/g) in all the nanocomposite packages except for the LDPE films with 1 $\% \mathrm{ZnO}$ nanoparticles. In the samples of LDPE films with $1 \% \mathrm{ZnO}$ nanoparticles, significant decreases $(\mathrm{p}<0.05)$ in yeast and mould counts were not observed during 4 days of storage compared to pure LDPE packages, indicating that the application of low mass fractions of $\mathrm{ZnO}$ nanoparticles is not sufficient for significant reduction of yeast and mould in a short period of time. Strawberries produce fermentation metabolites including acetaldehyde, ethanol and ethyl acetate under aerobic conditions, which can impact the flavour if they are present in higher amounts than their threshold values. Fermentation metabolism can be enhanced in fruits by several stress factors including environmental stress and microbial infections $(35,36)$. There is a correlation between the amount of ethanol and ethyl acetate production and the yeast counts in strawberries during cold storage. Ethyl acetate has been reported as an off-odour compound in strawberries. Yeast and moulds are the dominant flora on strawberries; if their microbiological count greatly increases, damaged spots will appear on the strawberries. The shelf life of fresh strawberries is defined as the time needed to reach yeast population of $5 \log \mathrm{CFU} / \mathrm{g}$ (37). The mean population of yeast and moulds remained below $5 \log \mathrm{CFU} / \mathrm{g}$ after the same storage time in all the packages except for the one made of pure LDPE films. However, it seems that the incorporation of $\mathrm{ZnO}$ nanoparticles into the LDPE film can reduce the microbial load of fresh strawberries and extend their shelf life by up to 16 days. Antimicrobial effects of $\mathrm{ZnO}$ nanoparticles may be attributed to several mechanisms: (i) induction of oxidative stress due to the generation of reactive oxygen species (ROS), such as $\mathrm{H}_{2} \mathrm{O}_{2}$, both in the interior and exterior of the cell, which leads to an interaction with proteins, DNA and lipids, causing cell death (38-41); (ii) membrane disorganisation due to the accumulation of $\mathrm{ZnO}$ nanoparticles in the bacterial cell walls and also their cellular internalisation (42), and (iii) release of $\mathrm{Zn}$ ions that may be responsible for antimicrobial activity by binding to the membrane of microorganisms (22). However, the toxicity of $\mathrm{ZnO}$ nanoparticles is not directly related to their entering the cell, but rather to their intimate contact with the cell that causes changes in the microenvironment in the vicinity of the contact area between the organism and the particle to either increase metal solubilisation or to generate ROS, which may ultimately damage the cell membrane (43). Moreover, the toxicity of $\mathrm{ZnO}$ nanoparticles is not only affected by the light through the formation of ROS, but may also occur in the dark although its mechanism is not yet defined (41). Jin et al. (25) studied the application of $\mathrm{ZnO}$ nanoparticles in food systems in several forms (as powder, polystyrene film and polyvinylpyrolidone gel) and concluded that these particles exhibit antimicrobial effects against Listeria monocytogenes, Salmonella Enteritidis and Escherichia coli in liquid egg white and in culture media. Moreover, Emamifar et al. (15) showed that the application of LDPE packages containing $\mathrm{ZnO}$ nanoparticles prolonged the shelf life of fresh orange juice, without any negative effect on sensory attributes. In another study, the same authors (44) observed reduced numbers of Lactobacillus plantaurum in sterilised orange juice when packed in LDPE film containing $\mathrm{ZnO}$ nanoparticles.

\section{Ascorbic acid degradation in strawberries}

Strawberries are a good source of nutritional compounds and are among fruits richest in ascorbic acid (45). The ascorbic acid content of fresh strawberries is from 19 to $71.5 \mathrm{mg}$ per $100 \mathrm{~g}$ (46). In most strawberry cultivars, it decreases with storage time, possibly because of the activity of ascorbate oxidase, which changes ascorbic acid to dehydroascorbic acid (47-49). According to Fig. 5, a significant decrease in the ascorbic acid content was observed in all the experimental packages during storage at $4{ }^{\circ} \mathrm{C}$. This overall ascorbic acid content reduction might be due to the nonbarrier properties of packaging against oxygen and the prolonged storage time $(46,50)$. Loss of ascorbic acid was significantly higher in pure LDPE films than in other packages, while the rates of these changes decreased with the increase of the mass fraction of $\mathrm{ZnO}$ nanoparticles in LDPE films with $5 \% \mathrm{ZnO}$ nanoparticles. After storage for 16 days, ascorbic acid content in strawberries in pure LDPE films decreased by about $96 \%$ (2.30 mg per $100 \mathrm{~g}$ ), while its content in the LDPE nanocomposites with 1,3 and $5 \% \mathrm{ZnO}$, and $3 \% \mathrm{ZnO}$ with PE-g-MA was $4.7,4.85,5.25$ and $6.55 \mathrm{mg}$ per $100 \mathrm{~g}$, respectively. Fig. 5 shows that the degradation rate of ascorbic acid content in LDPE films with $3 \% \mathrm{ZnO}$ nanoparticles and PE-g-MA was lower than in other samples.

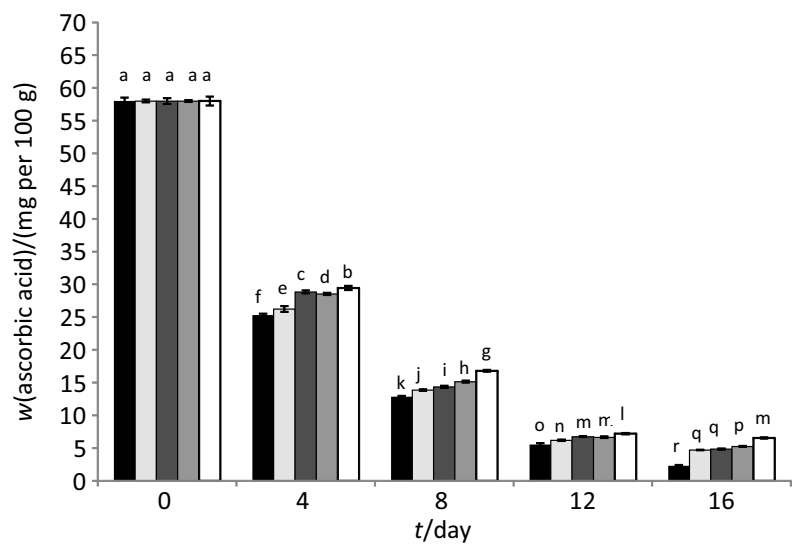

Fig. 5. Effect of packaging ( $\square$ pure LDPE films, $\square$ LDPE films with $1 \% \mathrm{ZnO}$ nanoparticles, $\square$ LDPE films with $3 \% \mathrm{ZnO}$ nanoparticles, $\square$ LDPE films with $5 \% \mathrm{ZnO}$ nanoparticles and $\square$ LDPE films with $3 \%$ ZnO nanoparticles and $10 \%$ PE-g-MA) on ascorbic acid content in fresh strawberries during 16 days of storage at $4{ }^{\circ} \mathrm{C}$. Different letters indicate significant differences at $p<0.05$ between nanocomposite packagings containing different mass fractions of $\mathrm{ZnO}$ nanoparticles and pure LDPE packaging 


\section{Titratable acidity of strawberries}

Citric acid is the most abundant organic acid in strawberry, followed by malic acid (51). The titratable acidity of fresh strawberries is in the range from 0.57 to $2.26 \%$ (52). The variations of acidity in strawberries are influenced markedly by time of storage, temperature, different cultivars and maturity stage of fruits (53-56). The titratable acidity of fruits decreased significantly during storage probably because of the increased rate of metabolism, especially respiration, which consumed the organic acid and thus decreased the acidity (2,57-59). In Fig. 6, a significant decrease in the titratable acidity of strawberries in all the experimental packages was observed during storage at $4{ }^{\circ} \mathrm{C}$. The loss of titratable acidity was significantly higher in the strawberries packaged in pure LDPE films than in other packages, while the rates of these changes decreased with the increase of $\mathrm{ZnO}$ nanoparticle mass fraction. The higher acidity of strawberries packaged in the nanocomposite containing $\mathrm{ZnO}$ during up to 16 days of storage could be related to the ROS generation mechanism by $\mathrm{ZnO}$ nanoparticles, which leads to interaction with proteins and respiratory enzymes (41).

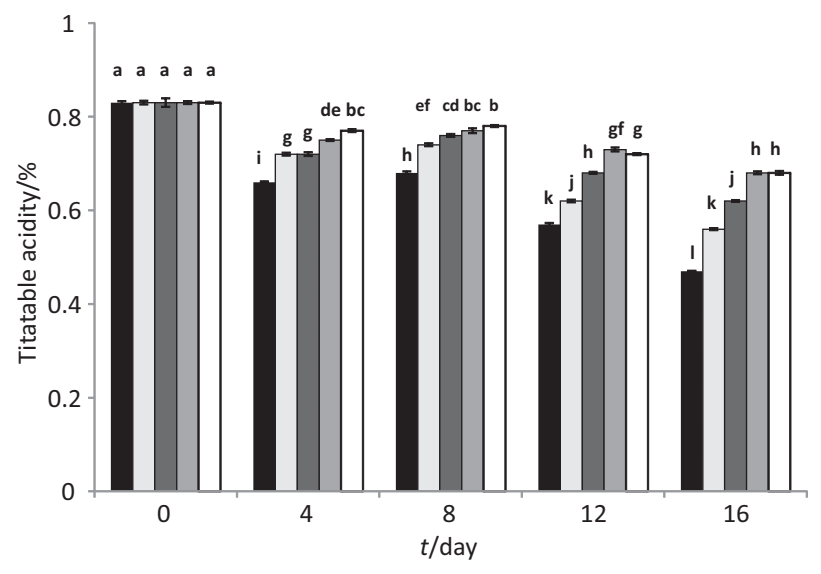

Fig. 6. Effect of packaging ( $\boldsymbol{\square}$ pure LDPE films, $\square$ LDPE films with $1 \% \mathrm{ZnO}$ nanoparticles, $\square$ LDPE films with $3 \% \mathrm{ZnO}$ nanoparticles, $\square$ LDPE films with $5 \% \mathrm{ZnO}$ nanoparticles and $\square$ LDPE films with $3 \% \mathrm{ZnO}$ nanoparticles and $10 \%$ PE-g-MA) on the titratable acidity of fresh strawberries during 16 days storage at $4{ }^{\circ} \mathrm{C}$. Different letters indicate significant differences at $\mathrm{p}<0.05$ between nanocomposite packaging containing different mass fractions of $\mathrm{ZnO}$ nanoparticles and pure LDPE packaging

\section{Conclusions}

This study showed a new approach to preserve and extend the shelf life of fresh strawberry at $4{ }^{\circ} \mathrm{C}$ by the application of LDPE packaging materials containing $\mathrm{ZnO}$ nanoparticles. These nanocomposite packaging films have a very effective antimicrobial activity because of good dispersion of nanomaterials in the polymer matrix free from agglomeration. The addition of polyethylene-grafted maleic anhydride into the polymer matrix resulted in a good dispersion of nanoparticles in the nanocomposite polymer matrix, which not only increased antimicrobial activity but also improved mechanical properties of nanocomposite polymers. The shelf life of fresh strawberries in packages containing $\mathrm{ZnO}$ nanoparticles was prolonged up to 16 days without any negative effects on the ascorbic acid content. However, storage of fresh strawberries in nanopackages is not sufficient for long-term storage. This study revealed that for prolonged shelf life of fresh strawberry, it is necessary to apply another treatment in combination with the nanopackages.

\section{Acknowledgements}

We gratefully acknowledge everyone who helped us in this research.

\section{References}

1. Jiang YM, Joyce DC, Terry LA. 1-Methylcyclopropene treatment affects strawberry fruit decay. Postharv Biol Technol. 2001;23:227-32.

http://dx.doi.org/10.1016/S0925-5214(01)00123-5

2. Vargas M, Albors A, Chiralt A, Gonzalez-Martinez C. Quality of cold-stored strawberries as affected by chitosan-oleic acid edible coatings. Postharv Biol Technol. 2006;41:164-71. http://dx.doi.org/10.1016/j.postharvbio.2006.03.016

3. Cagnon T, Méry A, Chalier P, Guillaume C, Gontard N. Fresh food packaging design: a requirement driven approach applied to strawberries and agro-based materials. Innov Food Sci Emerg Technol. 2013;20:288-98. http://dx.doi.org/10.1016/j.ifset.2013.05.009

4. Park SI, Stan SD, Daeschel MA, Zhao Y. Antifungal coatings on fresh strawberries to control mold growth during cold storage. J Food Sci. 2005;70:202-7.

http://dx.doi.org/10.1111/j.1365-2621.2005.tb07189.x

5. Caner C, Aday MS, Demir M. Extending the quality of fresh strawberries by equilibrium modified atmosphere packaging. Eur Food Res Technol. 2008; 227:1575-83. http://dx.doi.org/10.1007/s00217-008-0881-3

6. Jeyamkondan S, Jayas, DS, Holley RA. Pulsed electric field processing of foods: a review. J Food Protect. 1999;62:1088-96. http://dx.doi.org/10/1999; 62(9):1088-96

7. Deliza R, Rosenthal A, Silva ALS. Consumer attitude towards information on non-conventional technology. Trends Food Sci Technol. 2003;14:43-9. http://dx.doi.org/10.1016/S0924-2244(02)00240-6

8. Misra NN, Patil S, Moiseev T, Bourke P, Mosnier JP, Keener $\mathrm{KM}$, Cullen PJ. In-package atmospheric pressure cold plasma treatment of strawberries. J Food Eng. 2014;125:131-8. http://dx.doi.org/10.1016/j.jfoodeng.2013.10.023

9. Breitfellner F, Solar S, Sontag G. Effect of gamma-irradiation on phenolic acids in strawberries. J Food Sci. 2002;67:517-21. http://dx.doi.org/10.1111/j.1365-2621.2002.tb10629.x

10. Cao S, Ho Z, Pang B, Wang H, Xie H, Wu F. Effect of ultrasound treatment on fruit decay and quality maintenance in strawberry after harvest. Food Control. 2010;21:529-32. http://dx.doi.org/10.1016/j.foodcont.2009.08.002

11. Luksiene Z, Buchovec I, Viskelis P. Impact of high-power pulsed light on microbial contamination, health promoting components and shelf life of strawberries. Food Technol Biotechnol. 2013;51:284-92.

12. Aday MS, Temizkan R, Büyükcan MB, Caner C. An innovative technique for extending shelf life of strawberry: Ultrasound. LWT - Food Sci Technol. 2013;52:93-101. http://dx.doi.org/10.1016/j.lwt.2012.09.013

13. Erkan M, Wang YS, Wang YC. Effect of UV treatment on antioxidant capacity, antioxidant enzyme activity and decay in strawberry fruit. Postharv Biol Technol. 2008;48:163-71. http://dx.doi.org/10.1016/j.postharvbio.2007.09.028 
14. Sulaiman A, Silva FVM. High pressure processing, thermal processing and freezing of 'Camarosa' strawberry for the inactivation of polyphenoloxidase and control of browning. Food Control. 2013;33:424-8. http://dx.doi.org/10.1016/j.foodcont.2013.03.008

15. Emamifar A, Kadivar M, Shahedi M, Solaimanian-Zad S. Evaluation of nanocomposite packaging containing Ag and $\mathrm{ZnO}$ on the shelf life of fresh orange juice. Innov Food Sci Emerg Technol. 2010;11:742-8. http://dx.doi.org/10.1016/j.ifset.2010.06.003

16. Cushen M, Kerry J, Morris M, Cruz-Romero M, Cummins E. Nanotechnologies in the food industry - recent developments, risks and regulation. Trends Food Sci Technol. 2012; 24:30-46.

http://dx.doi.org/10.1016/j.tifs.2011.10.006

17. Chaudhry Q, Scotter M, Blackburn J, Ross B, Boxall A, Castle $\mathrm{L}$, et al. Applications and implications of nanotechnologies for the food sector. Food Addit Contam A. 2008;25:241-58. http://dx.doi.org/10.1080/02652030701744538

18. Cho IJ, Lee HS, Lim SJ, Koh JY, Kwak SH, Hwang GI. Detection and distribution of food-borne bacteria in ready-to-eat foods in Korea. Food Sci Biotechnol. 2011;20:525-9. http://dx.doi.org/10.1007/s10068-011-0073-y

19. Choudalakis G, Gotsis A. Permeability of polymer/clay nanocomposites: a review. Eur Polym J. 2009;45:967-84. http://dx.doi.org/10.1016/j.eurpolymj.2009.01.027

20. Marsh K, Bugusu B. Food packaging-roles, materials, and environmental issue. J Food Sci. 2007;72:39-55. http://dx.doi.org/10.1111/j.1750-3841.2007.00301.x

21. Del Nobile MA, Conte A, Buonocore GG, Incoronato AL, Massaro A, Panza O. Active packaging by extrusion processing of recyclable and biodegradable polymers. J Food Eng. 2009;93:1-6. http://dx.doi.org/10.1016/j.jfoodeng.2008.12.022

22. Gajjar P, Pettee B, Britt DW, Huang W, Johnson W, Anderson AJ. Antimicrobial activities of commercial nanoparticles against an environmental soil microbe, Pseudomonas putida KT2440. J Biol Eng. 2009;3:1183-9. http://dx.doi.org/10.1186/1754-1611-3-9

23. Yan D, Yin G, Huang Z, Yang M, Liao X, Kang Y, et al. Characterization and bacterial response of zinc oxide particles prepared by a biomineralization process. J Phys Chem. 2009; 113:6047-53.

http://dx.doi.org/10.1021/jp808805w

24. Jones N, Ray B, Ranjit KT, Manna AC. Antibacterial activity of $\mathrm{ZnO}$ nanoparticle suspensions on a broad spectrum of microorganisms. FEMS Microbiol Lett. 2008;279:71-6. http://dx.doi.org/10.1111/j.1574-6968.2007.01012.x

25. Jin T, Sun D, Su JY, Zhang H, Sue HJ. Antimicrobial efficacy of zinc oxide quantum dots against Listeria monocytogenes, Salmonella Enteritidis, and Escherichia coli O157:H7. J Food Sci. 2009;74:46-52.

http://dx.doi.org/10.1111/j.1750-3841.2008.01013.x

26. Li Q, Mahendra S, Lyon DY, Brunet L, Liga MV, Li D, Alvarez, PJJ. Antimicrobial nanomaterials for water disinfection and microbial control: potential applications and implications. Water Res. 2008;42:4591-602.

http://dx.doi.org/10.1016/j.watres.2008.08.015

27. Appendini P, Hotchkiss JH. Review of antimicrobial food packaging. Innov Food Sci Emerg Technol. 2002;3:113-26. http://dx.doi.org/10.1016/S1466-8564(02)00012-7

28. Damm C, Neumann M, Münstedt H. Properties of nanosilver coatings on polymethyl methacrylate. Soft Mater. 2006;3: 71-88. http://dx.doi.org/10.1080/15394450600766819

29. ASTM Method D882-00. Standard test method for tensile properties of thin plastic sheeting. ASTM International, West
Conshohocken, PA, USA; 2012.

http://dx.doi.org/10.1520/D0882-12

30. AOAC Official Method 967.21. Vitamin C (ascorbic acid) in vitamin preparations and juices: 2, 6 dichloroindophenol titrimetric method final action. Gaithersburg, MD, USA: AOAC International; 2003.

31. An DS, Park E, Lee DS. Effect of hypobaric packaging on respiration and quality of strawberry and curled lettuce. Postharv Biol Technol. 2009;52:78-83.

http://dx.doi.org/10.1016/j.postharvbio.2008.09.014

32. SAS/STAT Software, v. 6.12, SAS Institute Inc, Cary, NC, USA; 1996.

33. Abdul Majid R, Ismail H, Mat Taib R. Effects of polyethylene-g-maleic anhydride on properties of low density polyethylene/thermoplastic sago starch reinforced kenaf fibre composites. Iran Polym J. 2010;19:501-10.

34. Abdul Majid R, Ismail H, Mat Taib R. Effect of PE-g-MA on tensile properties, morphology and water absorption properties of LDPE/thermoplastic sago starch blends. PolymPlast Technol Eng. 2009;48:919-24. http://dx.doi.org/10.1080/03602550902995018

35. Purvis AC. Effects of film thickness and storage temperature on water loss and interval quality of seal packaged grapefruit. J Am Soc Hort Sci. 1983;108:562-6.

36. Pelayo C, Ebeler SE, Kader AA. Postharvest life and flavor quality of three strawberry cultivars kept at $5{ }^{\circ} \mathrm{C}$ in air or air/20 kPa CO 2 . Postharv Biol Technol. 2003; 27:171-83. http://dx.doi.org/10.1016/S0925-5214(02)00059-5

37. Ragaert P, Devlieghere F, Loos S, Dewulf J, Van Langenhove $\mathrm{H}$, Foubert I, et al. Role of yeast proliferation in the quality degradation of strawberries during refrigerated storage. Int J Food Microbiol. 2006;108:42-50.

http://dx.doi.org/10.1016/j.ijfoodmicro.2005.10.017

38. Sawai J, Shoji S, Igarashi H, Hashimato A, Kokugan T, Shimizu M. Hydrogen peroxide as an antibacterial factor in zinc oxide powder slurry. J Ferm Bioeng. 1998;86:521-2. http://dx.doi.org/10.1016/S0922-338X(98)80165-7

39. Sawai J. Quantitative evaluation of antibacterial activities of metallic oxide powders $(\mathrm{ZnO}, \mathrm{MgO}$ and $\mathrm{CaO})$ by conductimetric assay. J Microbiol Meth. 2003;54:177-82. http://dx.doi.org/10.1016/S0167-7012(03)00037-X

40. Sawai J, Yoshikawa T. Quantitative evaluation of antifungal activity of metallic oxide powders $(\mathrm{MgO}, \mathrm{CaO}$ and $\mathrm{ZnO})$ by an indirect conductimetric assay. J Appl Microbiol. 2004;96: 803-9. http://dx.doi.org/10.1111/j.1365-2672.2004.02234.x

41. Adams LK, Lyon DY, Alvarez PJJ. Comparative eco-toxicity of nanoscale $\mathrm{TiO}_{2}, \mathrm{SiO}_{2}$, and $\mathrm{ZnO}$ water suspensions. Water Res. 2006;40:3527-32. http://dx.doi.org/10.1016/j.watres.2006.08.004

42. Brayner R, Ferrari-Iliou R, Brivois N, Djediat S, Benedetti MF, Fiévet F. Toxicological impact studies based on Escherichia coli bacteria in ultrafine $\mathrm{ZnO}$ nanoparticles colloidal medium. Nano Lett. 2006;6:866-70. http://dx.doi.org/10.1021/nl052326h

43. Cioffi, N, Rai, M, editors. Nano-antimicrobials: progress and prospects. Heidelberg, Germany: Springer; 2012. http://dx.doi.org/10.1007/978-3-642-24428-5

44. Emamifar A, Kadivar M, Shahedi M. Solaimanian-Zad S. Effect of nanocomposite packaging containing $\mathrm{Ag}$ and $\mathrm{ZnO}$ on inactivation of Lactobacillus plantarum in orange juice. Food Control. 2011;22:408-13. http://dx.doi.org/10.1016/j.foodcont.2010.09.011

45. Derossi A, De Pilli T, Fiore AG. Vitamin C kinetic degradation of strawberry juice stored under non-isothermal conditions. LWT - Food Sci Technol. 2010;43:590-5. http://dx.doi.org/10.1016/j.lwt.2009.10.006 
46. Lee SK, Kader AA. Preharvest and postharvest factors influencing vitamin $C$ content of horticultural crops. Postharv Biol Technol. 2000;20:207-20.

http://dx.doi.org/10.1016/S0925-5214(00)00133-2

47. Spinardi AM. Effect of harvest date and storage on antioxidant systems in pears. Acta Hort. 2005;682:135-40. http://dx.doi.org/10.17660/ActaHortic.2005.682.11

48. Ahmed W, Butt MS, Sharif MK, Shahid M. Comparative estimation of alginate and soy based coatings on $\mathrm{pH}$ and vitamin C contents of strawberry (Fragaria ananassa L) at controlled climate chamber. J Food Process Technol. 2013;4:280. http://dx.doi.org/10.4172/2157-7110.1000280

49. Mishra R, Kar A. Effect of storage on the physicochemical and flavour attributes of two cultivars of strawberry cultivated in northern India. Sci World J. 2014;2014:Article ID794926. http://dx.doi.org/10.1155/2014/794926

50. Fellers PJ. Shelf life and quality of freshly squeezed, unpasteurized, polyethylene-bottled citrus juice. J Food Sci. 1988 53:1699-702. http://dx.doi.org/10.1111/j.1365-2621.1988.tb07819.x

51. Koyuncu MA, Dilmaçünal T. Determination of vitamin C and organic acid changes in strawberry by HPLC during cold storage. Not Bot Horti Agrobo. 2010;38:95-8. http://dx.doi.org/10.15835/nbha3834819

52. Cordenunsi BR, Oliveira do Nascimento JR, Genovese MI Lajolo FM. Influence of cultivar on quality parameters and chemical composition of strawberry fruits grown in Brazil. J Agric Food Chem. 2002;50:2581-6. http://dx.doi.org/10.1021/jf011421i
53. Spayd SE, Morris JR. Physical and chemical characteristics of pure from once-over harvested strawberries. J Am Soc Hort Sci. 1981;106:101-5.

54. Ayala-Zavala JF, Wang SY, Wang CY, Gonzalez-Aguilar GA. Effect of storage temperatures on antioxidant capacity and aroma compounds in strawberry fruit. LWT - Food Sci Technol. 2004;37:687-95. http://dx.doi.org/10.1016/j.lwt.2004.03.002

55. Ali A, Abrar M, Sultan MT, Din A, Nia B. Post-harvest physicochemical changes in full ripe strawberries during cold storage. J Anim Plant Sci. 2011;21:38-41.

56. Campos RP, Kwiatkowski A, Tonhi CD, Clemente E. Physical-chemical and microbiological characteristics of organic strawberries conserved with biofilms and refrigeration. J Food Res. 2012;1:247-56. http://dx.doi.org/10.5539/jfr.v1n3p247

57. Hernandez-Munoz P, Almenar E, Del Valle V, Velez D, Gavra R. Effect of chitosan coating combined with postharvest calcium treatment on strawberry (Fragariaxananassa) quality during refrigerated storage. Food Chem. 2008;110:428-35. http://dx.doi.org/10.1016/j.foodchem.2008.02.020

58. Ghafir SAM, Gadalla SO, Murajei BN, El-Nady MF. Physiological and anatomical comparison between four different apple cultivars under cold-storage conditions. Afr J Plant Sci. 2009;3:133-8.

59. Jan I, Rab A. Influence of storage duration on physico-chemical changes in fruit of apple cultivars. J Anim Plant Sci. 2012; 22:708-14. 